\title{
Impacted Teeth and Their Influence on the Caries Lesion Development
}

\author{
Amila Brkić \\ Sarajevo University, School of Dental Medicine, \\ Department of Oral Surgery and Dental Implantology, Sarajevo, \\ Bosnia and Herzegovina
}

\section{Introduction}

In oral and maxillofacial surgery removal of impacted teeth, especially third molars is one of the most performed surgical procedures. Several studies suggest that a millions of dollars are spend annually on the management of the impacted teeth (Edwards et al.,1999; Flick, 1999).

By definition, impacted or unerupted tooth is one that lying within the jaws and fails to erupt into the dental arch with the expected time (Jojić \& Perović, 1990; Hupp et al. 2008). Detected clinically and radiographically, there are two types of impactions; completely and partially. Completely impaction means that the tooth is prevented from completely erupting into a normal functional position, covered by bone and mucosa, while partially impaction implies that the tooth is partially visible or in communication with oral cavity, but it has failed to erupt fully into a normal position (Jojić \& Perović, 1990).

Any permanent tooth can become impacted (Gisakis et al.,2010). Impaction is an abnormality of development which predisposes to pathological changes and complications such as pericoronitis and / or orofacial infection, periodontitis, root resorption of adjacent teeth, caries, odontogenic cysts and tumors. Also orthodontic and prothetic problems including temporomandibular joint (TMJ) symptomes should not be neglected (Knutsson et al., 1996; Punwutikorn et al., 1999). Because of the mentioned, many authors to prevent these complications suggest so called "early or prophilactic removal of impacted teeth", although in cases of patients who are free of symptoms or associated, this necessity is under the question (Gisakis et al.,2010). Patients between 20 and 30 years of age are the most frequently affected with symptomatic impactions (Sasano et al.,2003; Knutsson et al. 1996). As age increases, the phenomen of impaction is reduced and after the age of 50 it is at range from 6-14\% (Ahlqwist \& Grondahl, 1991; Gisakis et al.,2010).

From the last 40 years, an incidence of impacted teeth is growing through different populations, due to living habits such as feading by a "soft food" and lower intensity of the use of the masticatory aparatus (Alling et al., 1993). Only a few decades earlier, Inuits and Latin American Indians through feading habits were described as the populations with no impacted teeth (Jojic \& Perović, 1990). Also, some authors suggest that race and gender have an influence on occurrence of impactions, thus the impactions are more common in Whites 
than Blacks (Brown et al., 1982), and females are more predisposed to this phenomenon than males (Jojic \& Perović, 1990). However, by Haidar and Schalhoub (1986) in Saudi population, especially in cases of impacted third molars, male are more prone to have an impacted teeth than female patients.

\section{Impacted teeth}

The reasons for tooth impaction might include a several factors such as position and size of adjacent teeth, dense overlying bone, excessive soft tissue or a genetic abnormality including abnormal eruption path, dental arch length and space in which to erupt (Jojic \& Perović, 1990; Alling et al., 1993; Hupp et al., 2008). Generally speaking these factors are subdivided into a two groups as local and general factors. The most common impacted teeth are mandibular and maxillary third molars, followed by the maxillary canines and mandibular premolars (Jojic \& Perović, 1990; Hupp et al., 2008). Third molars have inadequate space for eruption, thus they are the last teeth to erupt. New data suggests that $72,7 \%$ of the world population has at least one impacted tooth (usually lower third molar), and it is more frequently in female than the male patients (Ahlqwist \& Grondahl, 1991; Alling et al., 1993,).

Although indications for removal of impacted teeth vary from orthodontics, prosthodontics, pathologic and prophylactic, one of the reasons that impacted teeth should be removed, is their influence on the adjacent teeth with development of the caries lesions.

Caries is mentioned as one of the common pathological features associated with extracted mandibular third molars (Battaineh et al.,2002; Lysell \& Rohlin, 1988; Punwutikom et al., 1999). This is a reason why in this section the emphasis will be on these teeth.

There is an opinion that the tooth position and inclination play a main roles in caries development process (Knutsson et al.,1996). For better understanding this relationship it is necessary to know a classification of impacted lower third molars. The most common used classification is by Winter in which third molars are classificated by their long axis angulation with respect to the long axis of adjacent second molars. Mesioangular position is the most seen type of third molar impaction comprising $43 \%$ of all third molar impactions, characterized by mesial direction of the third molar's long axis toward to the second molar with convergency angle of $>30$ (Kan et al., 2002). In vertical position, the long axis of impacted tooth runs parallel to the long axis of the second molar comprising $38 \%$. Distoangular position including $6 \%$ of the cases is characterized by distally or posteriorly angled long axis of the tooth away from the second molar. If the long axis of the impacted tooth is perpendicular to the second molar comprising 3\% of all cases, this position is known as the horizontal (Kan et al., 2002; Hupp et al., 2008). However, atypic positions in which impacted teeth are angled in buccal, linqual, palatal or buccolinqual directions are also recorded (Jojic \& Perović, 1990; Hupp et al,. 2008). .

The second also in use classification is by Pell and Gregory, in which are described three positions of the third molars: depending of the relation of tooth to ramus and second molar subtypes (Type A), relative depth of the third molar in bone (Type B) tooth on same level with occlusal plane and position of long axis of the impacted tooth in relation to the second molar as taken from the Winter classification (Type C). (Kan et al., 2002; Hupp et al., 2008). 
The practice suggests that horizontal and mesioangular positions are more critical to adjacent second molar, because impacted teeth in these positions may impige and resorb a distal surface and root of the second molars (Knutsson et al.,1996).

\subsection{Winter classification of impacted lower third molars}

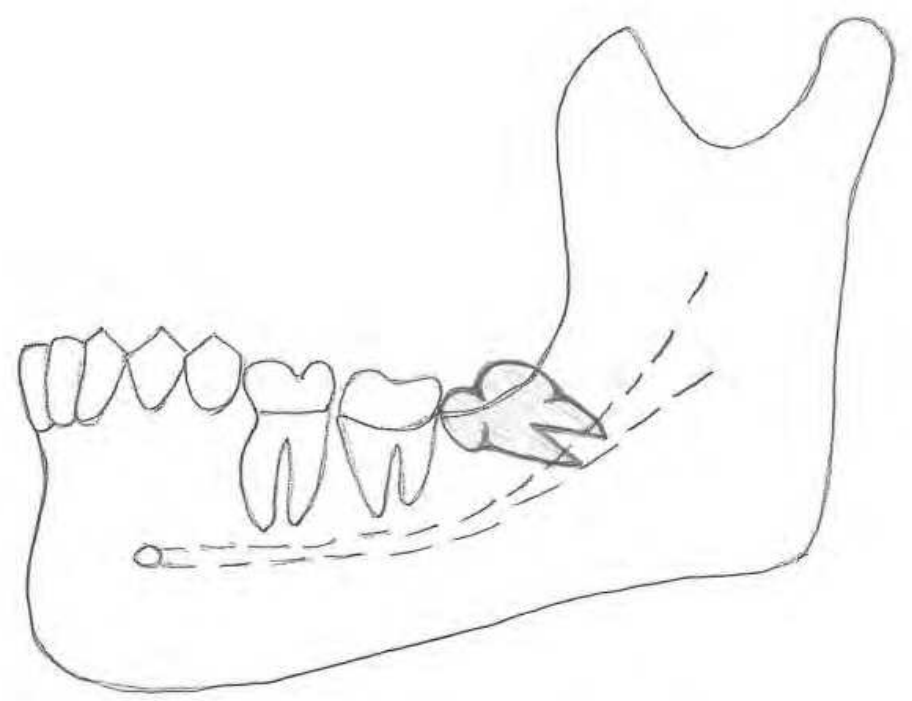

Fig. 1. Mesioangular position of the lower third molar.

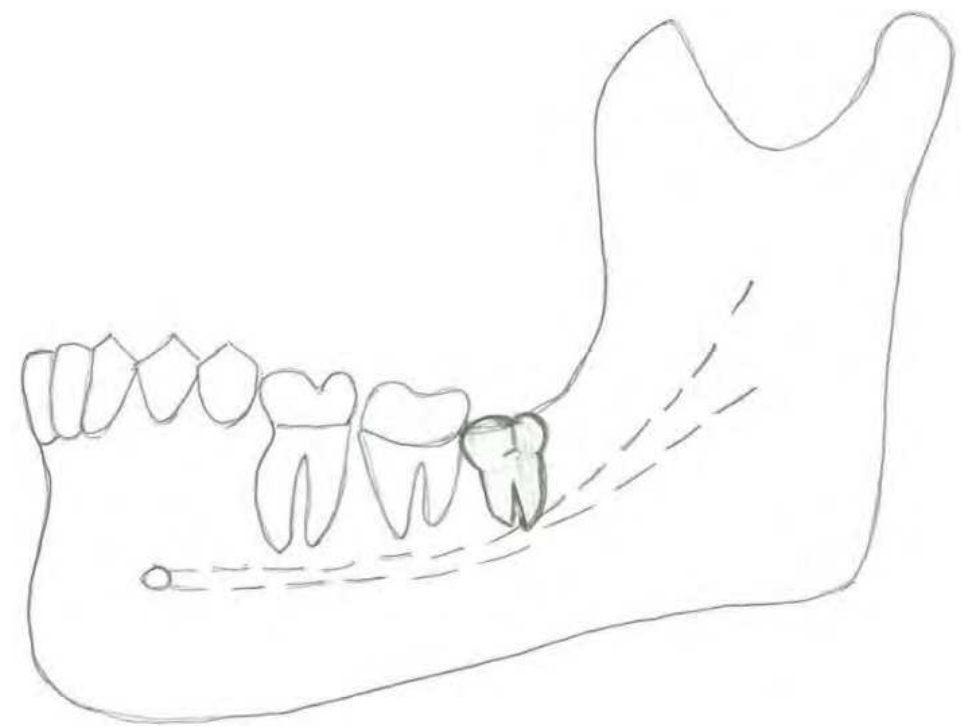

Fig. 2. Lower third molar in vertical position. 


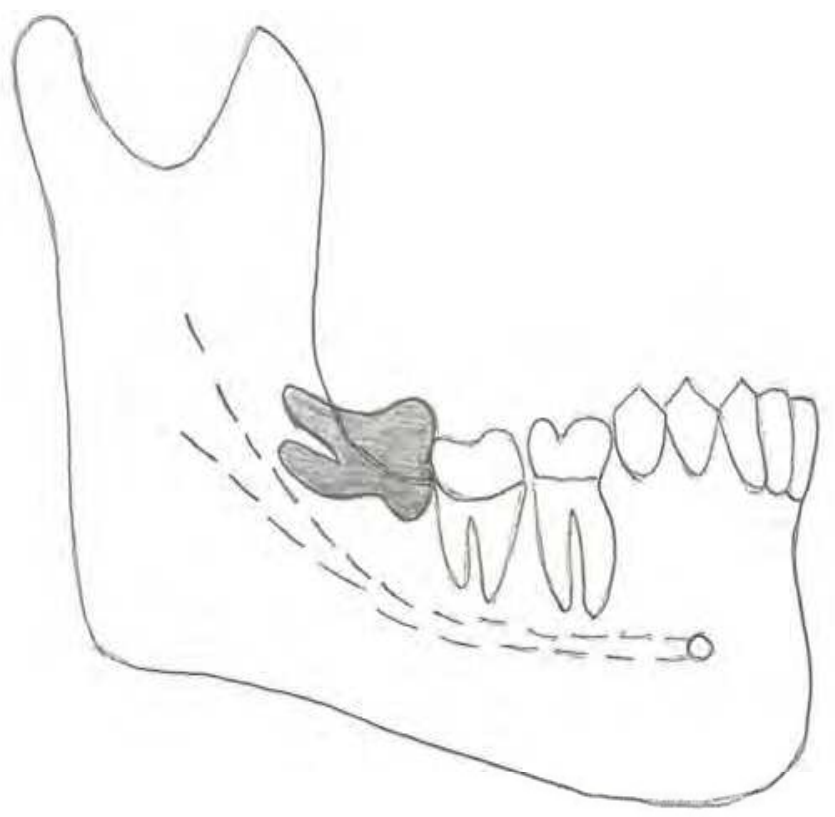

Fig. 3. Horizontal position of lower third molar.

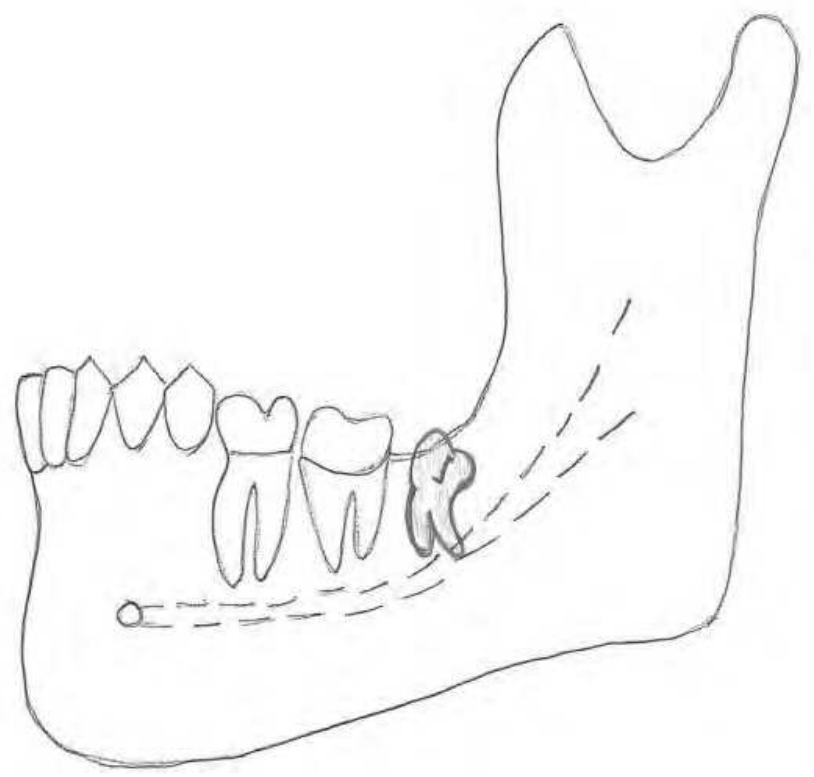

Fig. 4. Distoangular position of lower third molar. 


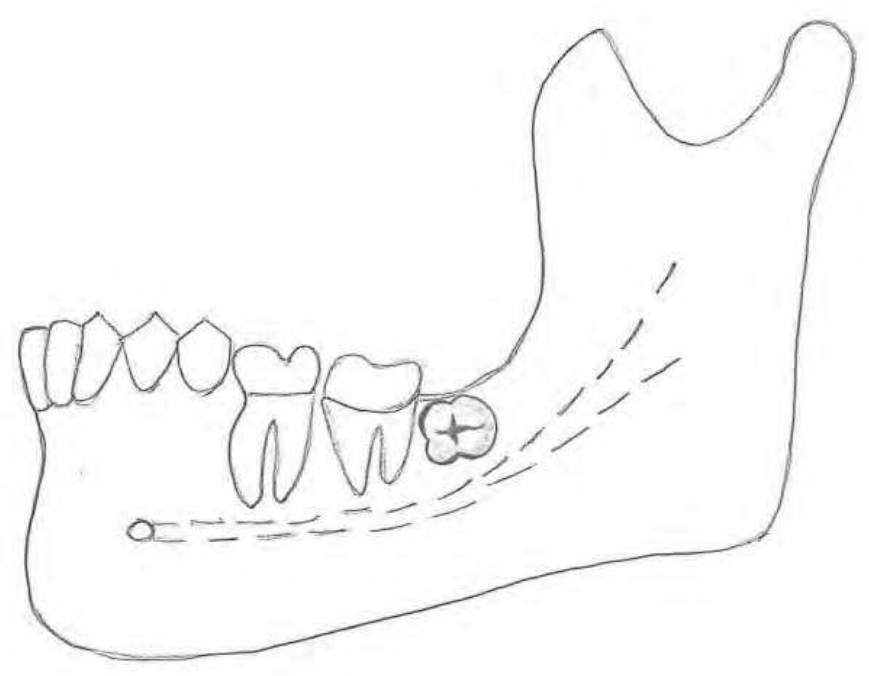

Fig. 5. Atipic position of the impacted tooth.

\section{Caries}

The most common causes of the tooth lost are caries and periodontal disease, following a tooth fracture (Jacobsen, 2008). Data suggests that in most industrialized countries $60-90 \%$ of school aged children and almost $100 \%$ of adult population are affected by tooth decay (Petersen et al., 2005), with the prevalence, which is more higher in female than male (Lukacs \& Largaespada, 2006; Ferraro \& Vieira, 2010).

Tooth decay or dental caries is defined as chronic, multifactoral disease characterised by localized destruction of hard tooth tissues. It attacks on the mineralized tissues resulting in demineralization and in some cases destruction of the matrix (Jacobsen, 2008) . By some authors dental caries starts as small subclinical demineralised subsurface, which following a periods of remineralization and demineralization, may progress or arrest (Walmsley et al., 2002). There is an opinion that approximatelly 50 different factors subdivided into a three groups are in correlation with caries etiology: The first group is formed of those factors associated with the host such as quality of saliva and bacterial flora (Streptococcus mutans, Streptococcus sanquis, Actinomyces and Lactobacillae are the most commonly isolated from the caries lesions. These microorganisms produce lactic acid, also known as the milk acid, responsible for the caries development). The second group includes outside factors such as diet and the substrate on which bacteria act, while the third group content a tooth itself and those features which either predispose to or resist carious attack (Jacobsen, 2008).

Caries can affect enamel, dentin and cement, with usually localization at the cementoenamel junction or in the cementum. However, in modern men grooves and fissure areas of the posterior teeth are the most common sites of decay (Newbrun,1989; Fejerskov \& Kidd, 2008). There is a relationship between debth of the fissures and caries susceptibility, due to fact that food debris and microorganisms impact in the fissures. This leads to conclusion 
that a tooth morphology is an important determinant for the caries development. Due to gingival recesions and loss of periodontal and bone support, the root of the tooth may be exposed to the mouth and caries may occur (Jacobsen, 2008).

\subsection{Impacted tooth - Caries}

During tooth eruption into the oral cavity, organic pellicle and cellular covering which protect an enamel surface, are disepearing and on this way open the gate to attach of the saliva and microorganisms to the enamel (Jacobsen, 2008). In cases of impacted teeth, partially exposed impactions are the most prone to develop caries. Partially erupted tooth does not participate in mastication and for this reason offer more favorable conditions for bacterial accumulation than fully erupted tooth.(Fejerskov \& Kidd, 2008) Due to fact that lower and upper third molars are the most common enclosed teeth, pericoronitis associated with bad oral hygiene and lesser self clening area, leads to food and microorganisam accumulation that can not be cleaned through normal brushings and flossing, causing a caries development. The crowns of mesio-angulary and horizontaly impacted third molars often interfares with registering pocket debth ( Lenug et al., 2005) . Gingival swelling and inflammation may lead to the impression that the lesion is hiden in the pocket ( Fejerskov \& Kidd, 2008; Jacobsen, 2008). It is interesting that even under the gums and situations in which no obvious communication between the mouth and impacted tooth exist, tooth decay might be developed. In cases of partially impacted teeth occlusal and approximal sides are the most commonly affected. In extremly cases, a tooth crown might be completelly destroyed by the lesion.

For mesio-angular and horizontal impacted lower third molars partially exposed in the oral cavity, occlusal surfaces form plaque accumulative crevices against the distal surfaces of the second molars (Chu et al., 2003). On this way they cause a distal cervical caries on the second molars, though estimates of the rate vary from $1 \%$ to $4.5 \%$, which is difficult to be restored without extractions of the impacted teeth. Also, as the gingival margin recedes enamel-cementum junction becomes exposed forming forming a bacterial retention side and on this way forming root surface caries (Jacobsen, 2008). McArdle \& Rentol.(2006) suggests that second molar caries indication is responsible for $5 \%$ of mandibular third molar teeth removals. However, data from different authors suggests that these numbers are higher. Thus, van der Linden et al. (1995) reported caries in $7.1 \%$ of impacted third molars and in $42.7 \%$ of adjacent molars ( 204 and 1227 of 2872 teeth respectively). In study of Adeyemo et al.(2008) caries and its sequela $(63,2 \%)$ was the major reason for the third molars extraction, followed by reccurent pericoronitis $(26,3 \%)$ and periodontitis $(9,2 \%)$. However in the study of Obiechina et al. (2001), pericoronitis and periodontal disease $(42,92 \%)$ were the major reasons for the third molar removals. The incidence of the caries was 13,95\%, and it was on the third place of the third molar teeth removal indications (Obiechina et al.,2001). Lysell \& Rohlin (1998) showed that caries was associated with impacted third molars and second molars in $13 \%$ and $5 \%$ of cases respectively, Sasano et al.(2003) noted that $14.5 \%$ of symptomatic impactions were associated with dental caries. The results of Bataineh et al. (2002) showed an overall caries rate of $23 \%$ in impacted molars and $0.5 \%$ in the second molars associated with impacted molars. Knutsson et al. (1996) reported a high caries frequency of $31 \%$ with impactions, which was more common in patients between 20 and 29 years, followed by the 30 to 39 year group. Gisakis et al. (2011) reported an incidence of 
caries of the impacted and / or adjacent teeth of 9,9\%. Allen et al. (2009) reported an incidence of $42 \%$ of the distal second molar caries associated with partially or completelly impacted third molars. By the same study distal angulation and the other types of inclinations were not associated with detectable caries (Allen et al.,2009) Chu et al. (2003) reported a caries rates in $2-3 \%$ of lower wisdom teeth, followed by $7,3 \%$ of the adjacent second molars. Because of the mentioned, some authors suggested that the early or prophylactic removal of a partially erupted mesioangular wisdom teeth could prevent distal cervical caries forming in the mandibular second molars (McArdle \& Renton, 2006).

Caries lesions of partially impacted or adjacent teeth may or may not be cavitated, which is very important due to the fact that in cavitated lesions biofilms are more difficult to be controled by oral hygiene procedures. Cavitated lesions are the result of "undisturbed" dental plaque. In some cases tooth decay in the form of so called "hiden caries" might be present. This caries is characterized by lesion in demineralized dentin which is missed on a visual examination, but is detected radiographically (Newbrun, 1989). Radiographically, the caries lesion is in form of radiolucent zone, due to the fact that demineralized hard teeth tissues such as enamel and dentin do not absorbe a X-rays (Newbrun, 1989). Some dental practitioners in the cases of the asymptomatic partially impacted lower third molars in the vertical positions with caries lesion development, performe conservative therapy as repair of the cavity with placeing a filling. However, for this approach, to avoid a risk for development of the recurrent caries, an appropriate indication is necessary. This means that the patient's good oral hygiene without presence of dental plaque must be present.

In extreme cases, the tooth decay might be developed with great extension on the partially impacted third molars and adjacent second molars, that could not repeared with final result of the both teeth extractions (Walmsley et al., 2002).

Comparing with lower third molars, upper wisdom teeth are not often seen as the causer of the adjacent teeth distal caries.

Excluding a third molars, other impacted teeth may be also associated with caries risk. However, these findings are not so often seen.

Impacted upper canine is mostly in correlation with a rooth resorptions of the neighboring teeth, caries lesions of second incisor and the first premolar are not often seen in cases of the partially impacted canines. A position and inclination of supernumerary teeth, a product of hiperactivity of the dental lamina, also have an influence on the caries lesion developments. Meziodens as the clinically the most common supernumerary tooth, responsible for diastema of the central incisors, depending of localization, may cause a palatinal cervical and mesial caries lesions of the central incisors. Distomolar a supernumerary tooth located distal of the third molar, although it is rarely seen, might cause a distal caries of the neighbouring tooth.

\section{Conclusion}

Partially impaction of third molars play an important role in caries development of adjacent teeth. Mesio angular and horizontal positions are responsible for development of the distal cervical caries on the second molars, which is difficult to be restore without an extraction of impacted teeth. Early or prophilactic removal of a partially erupted mesio-angular and 
horizontal third molars could prevent distal cervical caries forming in the mandibular second molar. However, if the second molar has caries or large restoration, or has been endodonticaly treated, removal of partially or completelly impacted wisdom teeth, must to be safely performed without injuring the second molar. As one of the complications, it is expectable to be fracture restoration or a portion of the carious crown.

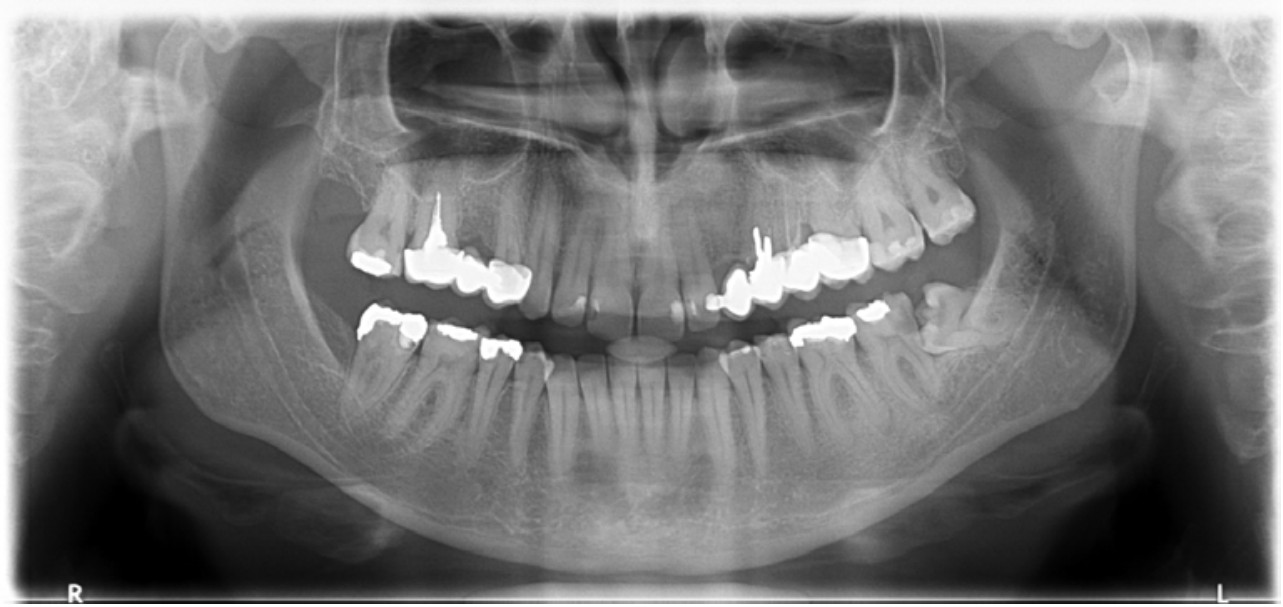

Fig. 6A. Partially impacted lower left wisdom tooth in horizontal position associated with the caries lesion on distal surface of the second molar.

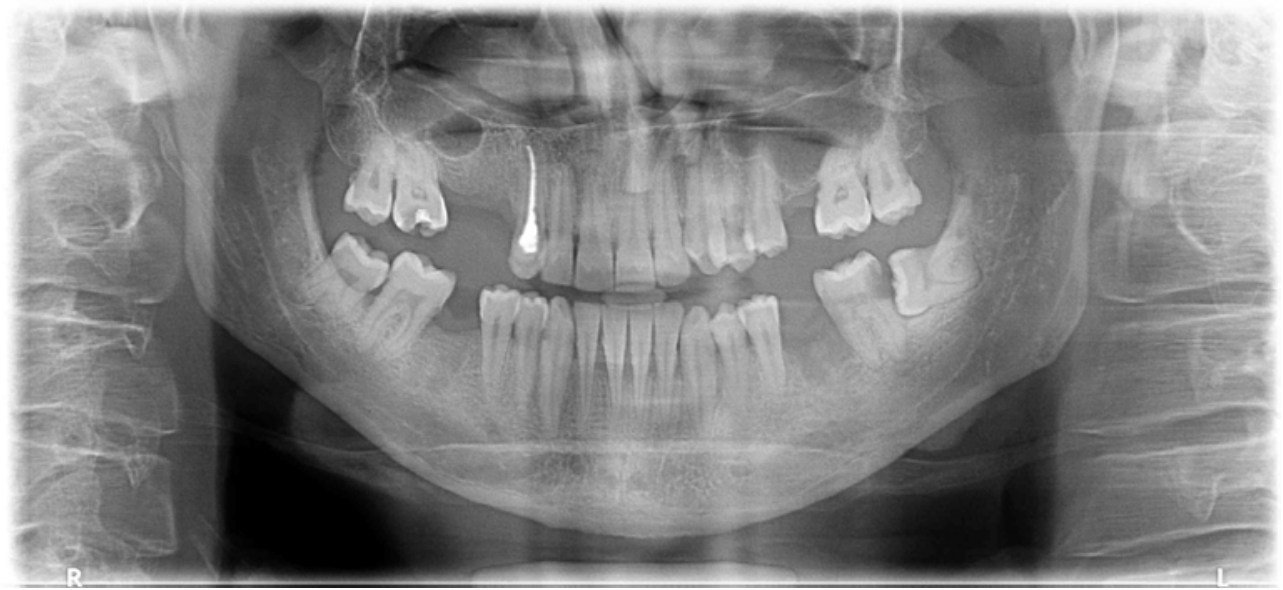

Fig. 6B. Partially impacted lower left wisdom tooth in horizontal position associated with the caries lesion on distal surface of the second molar. 


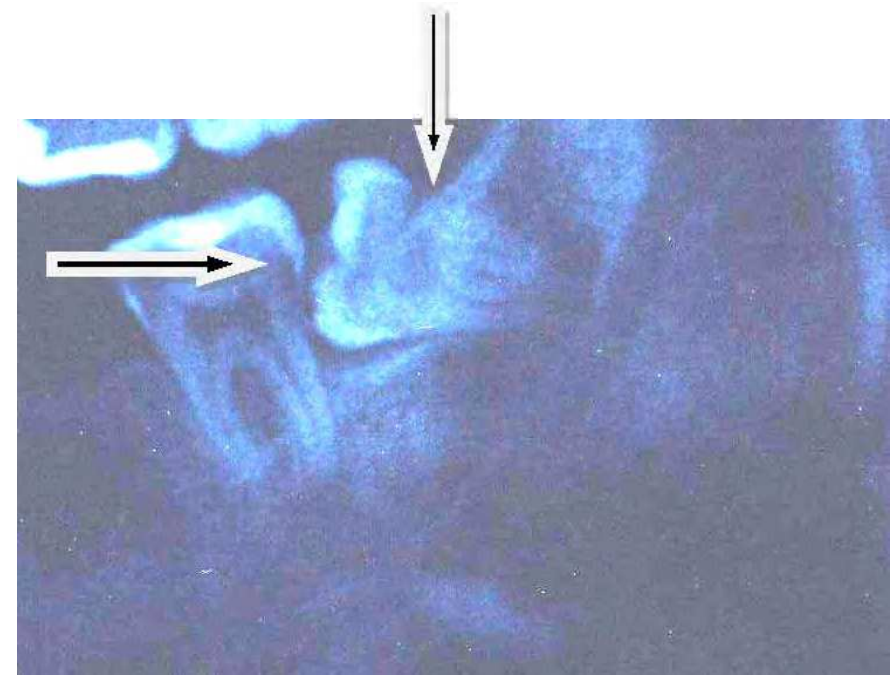

Fig. 7. The arrows show caries development on the distal surfaces of lower partially impacted third and second molar.

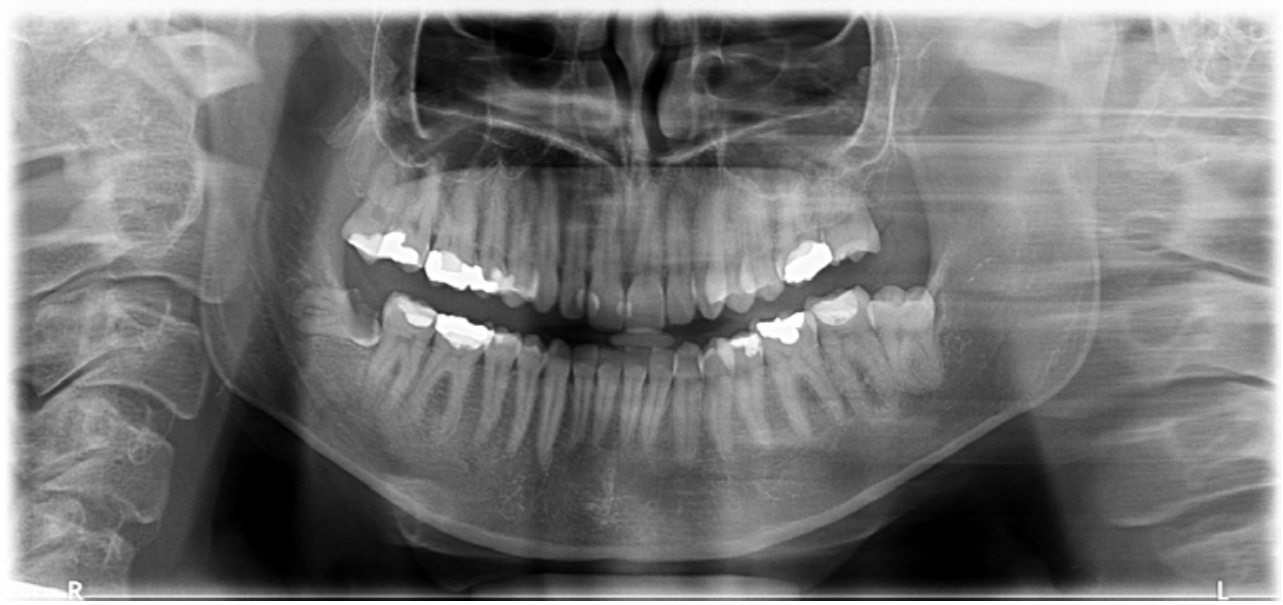

Fig. 8. Completelly destroyed by tooth decay, a crown of impacted lower right third molar tooth 


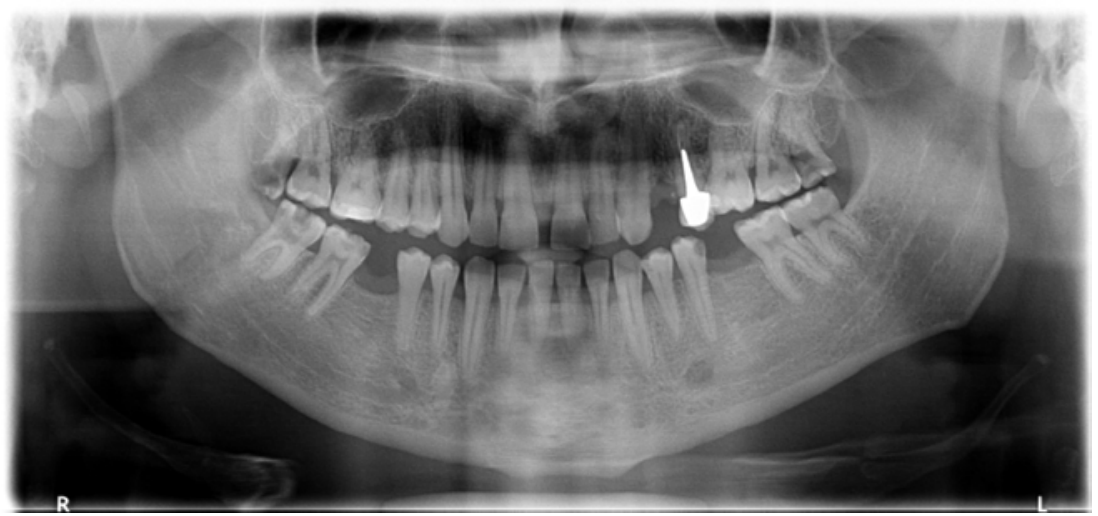

Fig. 9. Completelly destroyed by tooth decay, a crown of upper right third molar tooth.

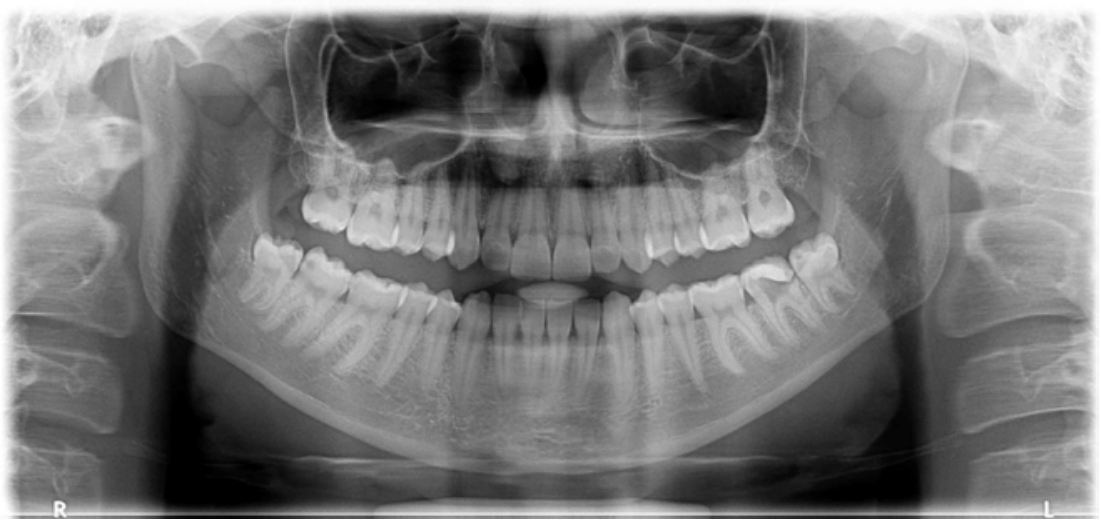

Fig. 10. Inadequate restoration of lower left second molar.

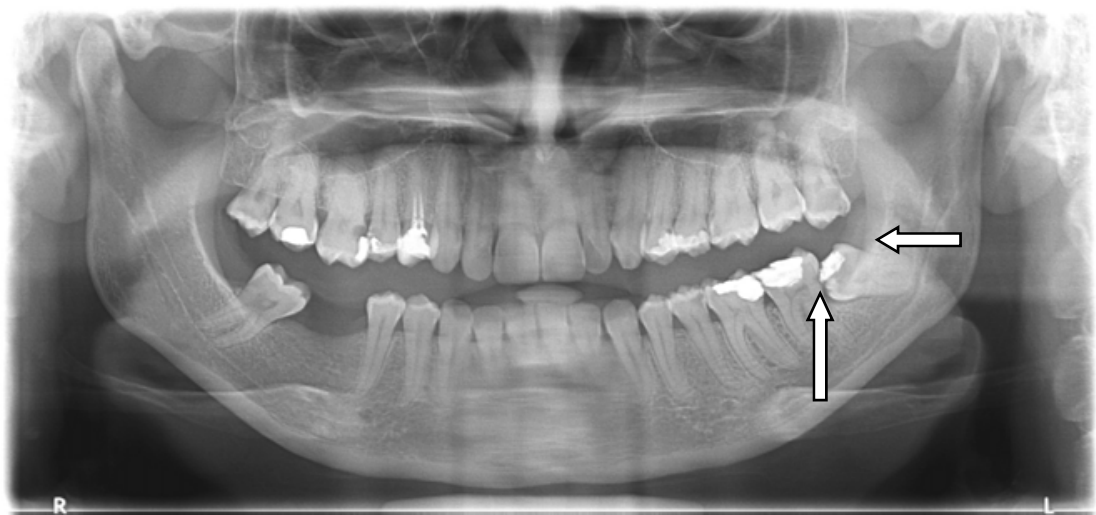

Fig. 11. Inadequate restoration of the oclusal surface of the lower left third molar. Arrows show a caries lesion beyond the filling and hiden caries of the distal surface of the second molar. 


\section{Acknowledgment}

The author thanks Mr. Enes Tuna for technical support of the manuscript preparation.

\section{References}

Adeyemo, W.L., James, O., Ogunlewe, M.O., Ladeinde, A.L., Taiwo, O.A. \& Olojede, A.C.(2008). Indications for extraction of third molars: a review of 1763 cases. Niger Postgrad Med J. Vol 15, No 1.pp. 42-46.

Ahlqwist, M. \& Gröndahl, H.G.(1991). Prevalence of impacted teeth and associated pathology in middle-aged and older Swedish women. Community Dent Oral Epidemiol. Vol 19, No 2. pp. 116-119.

Akadiri, O.A., Okoje, V.N., Fasola, A.O., Olusanya, A.A. \& Aladelusi, T.O.(2007). Indications for the removal of impacted mandible third molars at Ibadan--any compliance with established guidelines? Afr J Med Med Sci. Vol 36, No 4. pp.359-363.

Allen, R.T., Witherow, H., Collyer, J., Roper-Hall, R., Nazir, M.A. \& Mathew, G.(2009). The mesioangular third molar--to extract or not to extract? Analysis of 776 consecutive third molars. Br Dent J. Vol 206, No 11. pp. 586-587.

Alling C.C, Helfrick J.F \& Alling R.D. (1993). Impacted Teeth. W.B. Saunders. Philadelphia.

Bataineh, A.B., Albashaireh, Z.S. \& Hazza'a, A.M.(2002). The surgical removal of mandibular third molars: a study in decision making. Quintessence Int. Vol 33, No 8. pp. 613-617.

Chu, F.C, Li, T.K., Lui, V.K., Newsome, P.R., Chow, R.L. \& Cheung, L.K.(2003). Prevalence of impacted teeth and associated pathologies--a radiographic study of the Hong Kong Chinese population. Hong Kong Med J. Vol 9, No 3. pp.158-163. Edwards, M.J., Brickley,M.R., Goodey R.D.\& Shepherd J.P.(1999). The cost, effectiveness and cost effectiveness of removal and retention of asymptomatic disease free third molars. British Dental Journal. Vol 187, No 7. pp. 38-44.

Fejerskov, O. \& Kidd, E.(2008). Dental caries. The disease and its clinical management (2 nd edition), Blackwell Publishing Ltd, Oxford.

Ferraro, M. \& Vieira, A. R.(2010). Explaining gender differences in caries: a multifactorial approach to a multifactorial disease. Int J Dent. 2010:649643. Epub 2010 Mar 16.

Flick, M.G.(1999). Third molar controversy: framing the controversy as a public health policy issue. Journal of Oral and Maxillofacial surgery. Vol. 57, No 4. pp. 438-444.

Gisakis, I.G, Palamidakis, F.D., Farmakis E.T.R, Kamberos, G. \& Kamberos, S.(2011). Prevalence of impacted teeth in a Greek population. Journal of Investigative and Clinical Dentistry Vol 2, No2. pp.102-109.

Haidar, Z. \& Shalhoub, S.Y.(1986). The incidence of impacted wisdom teeth in a Saudi community. Int J Oral Maxillofac Surg. Vol 15, No 5. pp. 569-571.

Hupp, J.R, Ellis III, E. \& Tucker, M.R.(2008) Contemporary oral and maxillofacial surgery (5 $5^{\text {th }}$ edition), Mosby Elsevier, St. Louis, Missouri.

Jacobsen P.(2005). Restorative dentistry. An integrated approach (2nd edition), Blackwell Publishing Ltd, Singapore.

Jojić, B. \& Perović, J.V.(1990). Oralna hirurgija (4th edition ), Naučna knjiga, Beograd.

Kan, K. W., Liu, J. K. S., Lo, E. C. M., Corbet,E. F. \& Leung, W. K. (2002) Residual periodontal defects distal to the mandibular second molar 6-36 months after 
impacted third molar extraction. Journal of Clinical Periodontology Vol 29, No 11. pp. 1004-1011.

Knutsson, K., Brehmer, B., Lysell, L. \& Rohlin, M. (1996). Pathoses associated with mandibular third molars subjected to removal. Oral Surg Oral Med Oral Pathol Oral Radiol and Endod. Vol 82, No 1. pp.10-7.

Leung, W.K., Corbet, E.F., Kan, K.W., Lo, E.C. \& Liu, J.K. (2005) A regimen of systematic periodontal care after removal of impacted mandibular third molars manages periodontal pockets associated with the mandibular second molars. J Clin Periodontol. Vol 32, No 7. pp. 725-731.

Lukacs, J. R. \& Largaespada,L.L. (2006). Explaining sex differences in dental caries prevalence: saliva, hormones, and "life history" etiologies. American Journal of Human Biology, Vol. 18, No 4. pp. 540-555.

Lysell, L. \& Rohlin, M.(1998). A study of indications used for removal of the mandibular third molar. Int J Oral Maxillofac Surg. Vol 17, No 3. pp.161-164.

McArdle, L.W. \& Renton, T.F.(2006). Distal cervical caries in the mandibular second molar: an indication for the prophylactic removal of the third molar? Br J Oral Maxillofac Surg. Vol 44, No 1. pp. 42-45.

Newbrun, E (1989) Cariology (3rd edition), Quintessence publishing CO, Inc Chicago Illinois.

Obiechina, A. E., Arotiba, J.T. \& Fasola, A.O.(2001). Third molar impaction: evaluation of the symptoms and pattern of impaction of mandibular third molar teeth in Nigerians. Odontostomatol Trop. Vol 24, No 93. pp.22-25.

Petersen, P.E., Bourgeois, D., Ogawa, H., Estupinan-Day, S \& Ndiaye, C. (2005). The global burden of oral diseases and risks to oral health. Bulletin of the World Health Organization. Vol 83, No 9. pp. 661-669.

Polat, H.B, Ozan, F., Kara, I., Ozdemir, H.\& Ay, S. (2008). Prevalence of commonly found pathoses associated with mandibular impacted third molars based on panoramic radiographs in Turkish population. Oral Surg Oral Med Oral Pathol Oral Radiol Endod. Vol 105, No 6. pp. e41-47.

Punwutikorn, J., Waikakul, A. \& Ochareon, P.(1999). Symptoms of unerupted mandibular third molars. Oral Surg Oral Med Oral Pathol Oral Radiol Endod. Vol 87, No 3. pp.305310 .

Sasano, T., Kuribara, N., Iikubo, M., Yoshida A, et al. (2003). Influence of an angular position and degree of impaction of third molars on development of symptoms: Long term follow-up under good oral hygiene condition. Tohoku Journal of Experimental Medicine. Vol 200, No 2. pp.75-83.

Van der Linden, W., Cleaton-Jones, P. \& Lownie, M.(1995). Diseases and lesions associated with third molars. Review of 1001 cases. Oral Surg Oral Med Oral Pathol Oral Radiol Endod. Vol 79, No 2. pp. 142-145.

Walmsley, A.D, Walsh, T.F., Trevor Burke, F.J., Shortall, A.C.C., Lumley, P.J. \& Hayes Hall, R. (2002). Restorative dentistry. Churcil Livingstone. Edinburgh. 


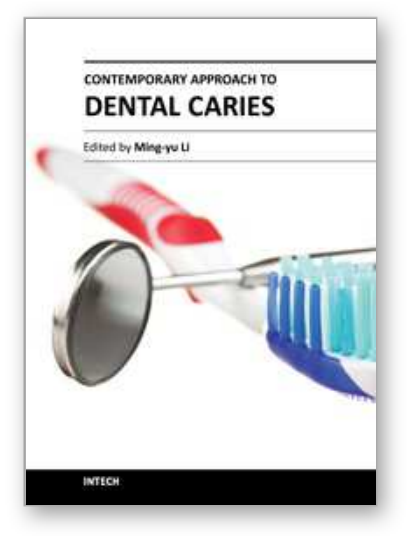

\author{
Contemporary Approach to Dental Caries \\ Edited by Dr. Ming-Yu Li
}

ISBN 978-953-51-0305-9

Hard cover, 488 pages

Publisher InTech

Published online 14, March, 2012

Published in print edition March, 2012

With an update of the recent progress in etiology, pathogenesis, diagnosis, and treatment of caries, it may be said that the final defeat of dental caries is becoming possible soon. Based on the research in this area in recent decades, "Contemporary Approach to Dental Caries" contained the caries in general, the diagnosis of caries, caries control and prevention, the medical treatment of caries, dental caries in children and others such as secondary caries. This book provides the reader with a guide of progress on the study of dental caries. The book will appeal to dental students, educators, hygienists, therapists and dentists who wish to update their knowledge. It will make you feel reading is profitable and useful for your practice.

\title{
How to reference
}

In order to correctly reference this scholarly work, feel free to copy and paste the following:

Amila Brkić (2012). Impacted Teeth and Their Influence on the Caries Lesion Development, Contemporary Approach to Dental Caries, Dr. Ming-Yu Li (Ed.), ISBN: 978-953-51-0305-9, InTech, Available from: http://www.intechopen.com/books/contemporary-approach-to-dental-caries/impacted-teeth-and-theirinfluence-on-the-caries-lesion-development

\section{INTECH}

open science | open minds

\section{InTech Europe}

University Campus STeP Ri Slavka Krautzeka 83/A 51000 Rijeka, Croatia Phone: +385 (51) 770447

Fax: +385 (51) 686166 www.intechopen.com

\section{InTech China}

Unit 405, Office Block, Hotel Equatorial Shanghai No.65, Yan An Road (West), Shanghai, 200040, China 中国上海市延安西路65号上海国际贵都大饭店办公楼405单元 Phone: +86-21-62489820

Fax: +86-21-62489821 
(C) 2012 The Author(s). Licensee IntechOpen. This is an open access article distributed under the terms of the Creative Commons Attribution 3.0 License, which permits unrestricted use, distribution, and reproduction in any medium, provided the original work is properly cited. 